\title{
Foreign direct investment behavior: Problemistic or slack search
}

\author{
Szu-Hsien Lin ${ }^{1,2 \star}$, You-Jie Chen ${ }^{1}$, Ai-Chi Hsu ${ }^{3}$, Ya-Chiu Angela Liu ${ }^{1}$ and Hung-Chih Wang ${ }^{1,4}$ \\ ${ }^{1}$ Department of Business Administration, National Chung Cheng University, Taiwan, R. O. C. \\ ${ }^{2}$ Department of Finance, TransWorld University, Taiwan, R. O. C. \\ ${ }^{3}$ Department of Finance, National Yunlin University of Science and Technology, Taiwan, R.O.C. \\ ${ }^{4}$ Department of Business Administration, Taiwan Shoufu University, Taiwan, R. O. C.
}

Accepted 27 May, 2011

\begin{abstract}
This study examines the behaviors of firms that engage in Foreign Direct Investments (FDIs). The present study is unique in adopting the classification of underperforming or outperforming, relative to aspiration level, to examine FDI behaviors. An analysis of the fixed-effects panel regression shows that the attainment discrepancy and the behaviors of their peer firms affect the listed Taiwanese firms' FDls into China. However, slack search is more appropriate than problemistic search in explaining firms' FDI behaviors. Shifts of managers' attention occur when firms face different situations. Managers may shift their attention from aspiration to survival when threats are present. The focal point of managers' attention can be more on unabsorbed slack or potential slack depending on whether firms are pursuing aspiration or survival. Understanding how the role of aspiration level and the shifts of managers' attention play in FDI behaviors can help outsiders such as investors and policymakers to identify firms' strategy and modify investment strategies or policies.
\end{abstract}

Key words: Foreign direct investment, the behavioral theory of the firm, the resource-based view of the firm, attainment discrepancy, slack search, problemistic search.

\section{INTRODUCTION}

This study examines the link between the risk-taking behaviors of firms and their performances relative to the aspiration levels, which play an important role in affecting firms' behaviors. The present study uses foreign direct investment (FDI) as a measure of risky behavior, since FDI inevitably involves doing business in another culture or environment where firms have to deal with uncertainty and unpredictable risk. As Chadee et al. (2003) suggest, different countries possess distinctive features of their own, such as physical, economic and political attributes, and these characteristics may affect the success of FDI. Especially when political factors are present, foreign investments include complications. The relationship between Taiwan and China is a typical example, and thereby this study employs FDI intensity to explore the search and decision making behaviors of Taiwanese

$\overline{{ }^{*} \text { Corresponding author. E-mail: aleclin.tw} @ g m a i l . c o m . ~}$ firms. As Chen and Miller (2007) suggest, the classic theory of firm behavior views organization as goaldirected systems that employ simple decision rules to alter their activities in response to performance feedback. Whereas, the resource-based view of the firm (Wernerfelt, 1984) describes firms as combinations of tangible and intangible resources, and the strategy selection comes from the cautious evaluation of the resources (Galbreath and Galvin, 2008). Problemistic and slack search appears to be a typical reflection of these two theories, and both have essential implications for management practice, generally causing organizations to undertake relevant risky behaviors, such as launching innovations or new investment projects.

Managers usually set out to enact problemistic searches when organizational performance is below the "aspiration level", which is the smallest outcome that decision makers view as satisfactory (Schneider, 1992). Cyert and March (1963) defines problemistic search as a search that originates from a problem and can direct 
firms toward finding a solution to that problem (Greve, 2003a). Managers finding organizational performance below their desired aspirations triggers problemistic search (Cyert and March, 1963). In contrast, organizations engage in slack search when they have excess resources (Chen and Huang, 2009; Greve, 2003a). Organizations with spare time and spare resources generally enjoys greater opportunities for experimentation and less strict performance monitoring, and therefore have the resources and managerial patience to perform searches (Greve, 2003b). Executive managers can set slack searches in place by allocating more resources for product developers to work on their own projects and apply looser performance standards for new projects (Jelinek and Schoonhoven, 1990).

In light of the above arguments, this study examines the role of aspiration level in the behaviors of those firms involved in FDIs and whether problemistic or slack search is more appropriate in explaining firms' FDI behaviors. As for firms in crisis or under a threat of bankruptcy, the literature also includes different viewpoints; for example, firms may take conservative stances to avoid placing themselves at risk (March and Shapira, 1987; Staw et al., 1981) or aggressive actions to find solutions for changing their situations. Therefore, this study also examines the FDI behaviors of firms directly under a threat of bankruptcy.

According to Greve (2003b), search and decision making jointly contributes to firm innovations, and this fact helps explain why firms' launching rates of innovation are variable over time and across organizations. Similar to firm innovations, FDI requires a lot of search and decision making process, which involves substantial costs of identifying investment opportunities and appropriate locations, coordinating suppliers, and acquiring knowledge of the local legal issues. As such, search and decision making also contributes to the different intensity of FDIs. With regard to the FDIs of Taiwanese firms, apart from the aforementioned search behavior, the firms inevitably have to face inherent country risks, especially the political risks in China.

Accordingly, this study focuses on whether FDI intensity depends on performance relative to aspirations, slack, and distance to bankruptcy for the Taiwanese enterprises.

\section{THEORY AND HYPOTHESES}

The behavioral theory of the firm (Cyert and March, 1963) focuses on the roles of the organizational processes of performance evaluation, search, and decision making. The theory provides testable propositions for examining how these processes affect the organizational changes of firms. At a later time, Greve (2003b) extends on Cyert and March (1963) and March's (1994) model and proposes a framework of search theory including the three procedures mentioned above. As Greve (2003b) suggests, recognizing that search and decision making jointly contributes to firm innovations helps explain why firms' launching rates of innovation are variable over time and across organizations. The decision making process includes managers' risk preference (Kahneman and Tversky, 1979, 1991) and decision makers' risk tolerance level (March, 1994), which serve as the criteria for the solution and execution of investment opportunities. According to the prospect theory, decision makers will be more risk averse when viewing situations as gains, and more risk seeking when viewing situations as losses (Kahneman and Tversky, 1979, 1992). Some behavioral arguments about risk taking also contend that the decision makers would try to find solutions and take highrisk projects when their performances are below the firms' aspiration levels (Greve, 1998, 2003a; Grinyer and McKiernan, 1990; Miller and Leiblein, 1996), and reorientate their strategies (Audia et al., 2000; Greve, 1998; Lant, 1992; Lant et al., 1992).

Miller and Chen (2004) suggest that organizations performing poorly would typically increase risk taking when under a threat of bankruptcy, and decrease risk taking as their performances improve. Their findings provide evidence for aggressive actions toward finding solutions to change firms' bad situations. As Jensen and Meckling (1976) suggest, the limited feature of equity claims allows risk shifts from shareholders to creditors. To extend, firms facing a threat of survival and even bankruptcy, agency problem may occur. That is, managers may take high-risk investment behaviors, or even thereby transfer firms' assets to other countries.

In contrast, as McNamara and Bromiley (1997) and Staw et al.(1981) suggests, a "threat-rigidity response" occurs among both individuals and organizations. In other words, when focusing on the likelihood of surviving, managers recognize their specific duties of avoiding their firms in risky situations and may avoid new activities or take aggressive actions (March and Shapira, 1987; Staw et al., 1981). Given the above ambiguity, March and Shapira (1987, 1992), argue against the practice of a single reference level and classify risk preference into two alternative targets. One is survival level: the managers focusing on survival are more risk averse, but are willing to take on greater risks as organizational performance improves, and the other is aspiration level: the managers focusing on an aspiration level are more risk taking when their organizational performances diverge from the target in either direction. Miller and Chen (2004) conduct an empirical test using March and Shapira's $(1987,1992)$ models, and find support for March and Shapira's general claim that the risk preferences differ across firms in three situations: (1) firms threatened by bankruptcy, (2) firms not directly threatened by bankruptcy but performing below their aspiration levels, and (3) firms performing above their aspiration levels.

Firms performing below desired aspiration levels 
usually seek ways to enhance their prospects to achieve target performance goals (Greve, 1998; 2003b). For underperforming firms, increasing performance variability may improve the probability of achieving their desired aspirations (March and Shapira, 1992; Singh, 1986). According to Bowman (1982) and Fiegenbaum and Thomas (1986; 1988), risk taking of aspiration-focused firms would increase with the distance below their aspiration levels. Miller and Chen (2004) test whether risk taking increases in proportion to the distance below aspiration levels, when a firm is not threatened by bankruptcy, and find that the negative effects of performance on risk taking are consistently larger for the firms with moderate performances than those with either low or high performances. Kogut (1983) suggests that firms can view foreign direct investments as high risk projects, and therefore performance and risk preference are relevant to the decision behaviors of FDIs

According to the above arguments, an aspirationfocused firm may take greater risks the further the performance falls below the aspiration level. This study therefore sets out to test whether the firms with performances under their aspiration levels choose FDI to improve their performance.

$\mathbf{H}_{1 \mathbf{a}}$ : FDI intensity increases with the distance of firms' performance below aspirations.

According to prospect theory, managers finding their performances below aspiration levels would be risk taking, whereas managers finding their performances above aspiration levels would be risk-averse (Kahneman and Tversky, 1979, 1992). In addition, the probability of organizational changes decreases as firms improve their performances relative to aspirations (Greve, 1998). On the other hand, March and Shapira's (1987) study suggests that aspiration-focused firms with more wealth may even become more risk seeking. The managers of the firms performing above their aspiration levels are risk averse but become less so when their performances improve (Miller and Chen, 2004). This study therefore hypothesizes:

$\mathbf{H}_{\mathbf{1 b}}$ : The FDI intensity of firms performing above their aspiration levels decreases with the distance to performance.

March (1981) suggest that abundant organizational resources allows for more experimentation and organizational change. Executive managers can launch slack searches by allocating amounts of time for product developers to work on their own projects and applying looser performance standards for new projects (Jelinek and Schoonhoven, 1990). For organizations, spare time and slack resources imply greater opportunities for experimentation and less strict performance monitoring. Accordingly, firms can have the resources and patience to perform innovation search (Greve, 2003b). Meanwhile, the resource-based view of the firm suggests that firms are combinations of resources (Barney, 1986; Wernerfelt, 1984), and thus resources play an essential role in the strategy selection. This study therefore hypothesizes:

$\mathbf{H}_{2}$ : FDI intensity increases with firms' slack resources.

March and Shapira's $(1987,1992)$ model of managers' risk preferences allows for shifts in attention between survival and aspiration levels. Staw et al. (1981) suggest that firms avoid launching new activities when their survival is threatened. According to the threat-rigidity effect, organizations may respond to threat by taking restricted information processing, tightened control and conservation of resources (Miller and Chen, 2004). However, for firms not directly threatened by bankruptcy, their foci may change to aspiration and more likely to take risk as their performances get worse. Miller and Chen (2004) find that organizations performing poorly would typically increase risk taking when near bankruptcy, and decrease risk taking as their performances improve. This study therefore hypothesizes:

$\mathbf{H}_{3 \mathbf{a}}$ : If a firm is directly threatened by bankruptcy, its FDI intensity decreases when more approaching bankruptcy.

$\mathbf{H}_{3 b}$ : If a firm is not directly threatened by bankruptcy, its FDI intensity increases as the distance to bankruptcy decreases.

\section{DATA AND METHODS}

The data for this study come from the database of the Taiwan Economic Journal (TEJ), which collects operational and financial information for all publicly traded companies in Taiwan. Given the government's policy that prohibits the financial industry from investing in China during the study period, this study examines the FDIs of the manufacturing companies listed in TSE and OTC from 1997 to 2006. We excluded extreme outliers that are more than four standard deviations for regressors, including negative attainment discrepancy, positive attainment discrepancy, unabsorbed slack, potential slack, and Altman's Z, thus eliminating $2.525 \%$ of samples. After excluding extreme outliers, we obtained 7,290 observations in the sample.

\section{Dependent variable}

The dependent variable reflects firms' search and risk-taking related expenditures adjusted by firm size. This study uses the FDI intensity, a ratio of Taiwanese firms' annual investments in China to total assets, as a proxy variable for search intensity and risky behaviors jointly.

\section{Independent variables}

\section{Attainment discrepancy}

Attainment discrepancy is performance minus aspiration. Performance relative to aspiration is relevant to managers when making resource allocation decisions. Previous research such as 
Bromiley (1991) set up models viewing risk taking as a function, not of cumulative wealth, but of other performance indicators. Prior studies of Bromliey (1991) and Miller and Chen (2004) employ past ROA and ROA aspirations as performance indicators. This study followed this approach by adopting the return on assets (ROA) (net income divided by total assets) to measure performance, and lags performance one year relative to the dependent variable (Chen and Miller, 2007). As for aspiration, Cyert and March (1963) propose that organizations typically base their aspirations on their own past performances and on the experiences of peer firms, and therefore model aspiration as a linear combination of these variables. Some subsequent empirical studies about risk taking (Bromiley, 1991; Greve, 2003b; Chen and Miller, 2004, 2007; Wiseman and Bromiley, 1996) have followed this approach. Considering that firms may emphasize their own performances or other firms' performances when setting the aspiration levels (Baum, et al. 2005; Chen and Miller, 2004, 2007; Greve, 2003b). Hence, the study followed the cited researchers (Bromiley, 1991; Wiseman and Bromiley, 1996; Greve, 2003b; Miller and Chen, 2004, 2007) to adopt two different aspiration proxies in the models. One is the past performance of its own and the other is industry's mean past performance. Therefore, in this study, both represent the performance of two years prior to the dependent variable. In other words, firm aspiration is the specific firm's performance in year t-2; industry aspiration is industry's mean of performances in year t-2.

\section{Slack variables}

Organizational slack plays an important role in releasing resources for discretionary investment in growth opportunities (Chen and Huang, 2009). Earlier researchers, such as Greve's (2003b) study, use three measures of slack variables to study on firms' project investment and development. Absorbed slack is the ratio of selling general, and administrative expenses (SGAE) to sales (Singh, 1986; Reuer and Tong, 2007). Unabsorbed slack is the ratio of quick assets (cash and marketable securities) to liabilities (Greve, 2003b). Potential slack is the ratio of debt to equity (Bromiley, 1991; Greve, 2003a). Since the absorbed slack, which represents slack committed in salaries, overhead expense and various other administrative costs, is irrelevant to future investments, the study uses the unabsorbed slack and potential slack (Greve, 2003b) as proxy variables of organizational resources.

A greater organizational slack and borrowing ability is helpful for search behaviors and risky solutions. Unabsorbed slack coefficients are expected to be positive since unabsorbed slack represents a firm's available financial resources. Potential slack coefficients are expected to be negative in that lower ratio of debt to equity means more potential borrowing capacity and may facilitate more future investments. Chen and Miller (2007) suggest that organizational slack acts as an important catalyst for generating innovation; search plays a key role in organizational adaptation. Indeed, slack search provides an alternative source of solutions to organizational problems (Greve, 2003b) and risk taking (Miller and Chen, 2004). In the analyses of FDI intensity, the study lags the slack variables to test Hypothesis 2.

\section{Altman's Z variable}

The Altman's Z (1983), a bankruptcy predicting model created by Edward Altman in the 1968, is often used to measure a firm's proximity to bankruptcy. The Altman's Z Score is useful for examining whether a firm increases risk taking to improve its performance when approaching bankruptcy (March and Shapira, 1992; Singh, 1986). Altman's Z gradually receives some attention in previous strategic management research on risk (Chen and Miller 2007; D'Aveni and llinitch, 1992; Deephouse and Wiseman, 2000;
Miller and Leiblein, 1996; Miller and Chen, 2004). The calculation for Altman's Z is as follows:

(1.2 $\times$ working capital divided by total assets $)+$

$(1.4 \times$ retained earnings divided by total assets $)+$

$(3.3 \times$ income before interest expense and taxes divided by total assets) +

$(0.6 \times$ market value of equity divided by total liability $)+$

(1.0 $\times$ sales divided by total assets)

Because lower Altman's Z means a higher likelihood of bankruptcy, this study uses the means of Altman's $Z$ as a base to split the sample into two sub-samples and has separate tests on Hypothesis $3 a$ and $b$ to examine whether the proximity to bankruptcy affects FDI intensity.

\section{Control variables}

To effectively test the effects of attainment discrepancy, organizational slack and Altman's Z on FDI intensity, this study controls several industry-level and firm-level variables that may affect FDI intensity. Industry-level variables include industry average FDI intensity, and the average growth of industry's sales. We classified industries in the same way as the Taiwan Stock Exchange (TSE). Industry average FDI intensity is the ratio of investment to total asset. The average growth of industry's sales is the annual average growth percentage of industry's sales. The industry variables are lagged one year relative to the dependent variables.

Firm-level control variables include Research and Development intensity and Gross Profit Margin. Previous research (Greve, $2003 \mathrm{~b}$ ) uses $R$ and $D$ intensity as a proxy of risky behavior. Since $R$ and $D$ expenditure plays an important role in firms' search activities, the present study controls for $R$ and $D$ intensity to prevent the interaction effects of $\mathrm{R}$ and $\mathrm{D}$, and controls for gross profit margin to avoid the disturbance by the effects of gross profit margins upon the decision making policy regarding FDIs.

\section{Models}

\section{Spline function}

To test for the different effects on FDI of two situations when a firm's performance is above or below aspiration level, we specified performance as a spline function (Greene, 2008). The spline specification is to enter separate variables for performance above and below aspiration level, a procedure that provides separate tests for performances of being above and below aspiration level. Following Chen and Miller (2007), we used an indicator variable as the spline function specification to compare the differentials of performances above and below aspiration level, in the same model. $\mathrm{I}=1$ stands for an underperforming firm whose past performance falls below aspirations, and $I^{*}\left(\right.$ performance $i, t-1^{-}$aspiration $i, t-1$ ) serves as negative attainment discrepancy variable; whereas $I=0$ indicates an outperforming firm whose past performance meets or exceeds firm-specific aspirations, and $(1-I)^{\star}($ performance $i, t-1-$ aspiration $\mathrm{i}, \mathrm{t}-1)$ serves as negative attainment discrepancy variable.

$$
\begin{aligned}
F_{i, t}= & \beta_{1}+\beta_{2}+\beta_{3} F_{\text {ind }, t-1}+\beta_{4} G_{\text {ind }, t-1}+\beta_{5} I\left(P_{i, t-1}-A_{i, t-1}\right)+\beta_{6}(1-I)\left(P_{i, t-1}-A_{i, t-1}\right) \\
& +\beta_{7} U S_{i, t-1}+\beta_{8} P S_{i, t-1}+\beta_{9} R D_{i, t}+\beta_{10} Z_{i, t}+\beta_{11} M_{i, t}+\varepsilon_{i, t}
\end{aligned}
$$

The dependent variable, $F_{i, t}$, denotes firm i's FDI intensity in year $t$. The model includes explanatory variables for firm specific and time effects ( $\beta 1$ and $\beta 2$ ). Industry average FDI intensity, $F_{\text {ind, }}$, is lagged one year with the dependent variable. $G_{\text {ind, } t-1}$ is the percentage 
growth of industry's annual sales relative to the prior year, controlling for the prospects of market and product in industry that may influence search investments. $P_{i, t-1}$ and $A_{i, t-1}$ are measures of firm i's performance and aspiration level in time ${ }_{t-1}$. U $S_{i, t-1}$ denotes unabsorbed slack at time ${ }_{t-1}$. $\mathrm{PS}_{\mathrm{i}, \mathrm{t}-1}$ denotes potential slack at time $\mathrm{t}_{\mathrm{t}}$ 1. The use of lagged independent variables is to reflect the temporal ordering in our causal arguments. $R D_{i, t}$, denotes firm i's $R$ and $D$ search intensity in year $t$, which is a ratio of $R \& D$ expenditure to total asset. $Z_{i, t}$, denotes firm i's Altman's $Z$ in year $t$. $M_{i, t}$, denotes firm i's gross profit margin in year t. $\varepsilon_{i, t}$ is the error term.

\section{Split point of variables}

This study uses the means of unabsorbed slack, potential slack and Altman's Z to split the full sample into low and high sub-samples, in order to examine the risk taking behaviors among different environments and firm-specific conditions. The attainment discrepancy $\left(P_{i, t}-A_{i, t}\right)$ serves as a variable to explain the FDIs of both the high and low sub-samples:

$$
\begin{aligned}
F_{i, t}= & \gamma_{1}+\gamma_{2}+\gamma_{3} F_{i n d, t-1}+\gamma_{4} G_{i n d, t-1}+\gamma_{5}\left(P_{i, t-1}-A_{i, t-1}\right)+\gamma_{6} U S_{i, t-1}+\gamma_{7} P S_{i, t-1} \\
& +\gamma_{8} R_{i, t}+\gamma_{9} Z_{i, t}+\gamma_{10} M+\varepsilon_{i, t}
\end{aligned}
$$

\section{Fixed-effects model}

According to Greene (2008), the significance of the $F$ test in this study indicate the existence of fixed effects (Greene, 2008) and hence the use of panel data. Panel data are useful for controlling for individual heterogeneity and reducing the multicolinearity problem as well as omitted variable bias (Greene, 2008). Then, the Hausman test (Greene, 2008; Wooldridge, 2006), which is commonly used in the literature for testing the consistency of the Generalized Least Squares(GLS) estimator, rejects the use of random-effects model, leaving the fixed-effects model as the better selection. The fixed-effects model treats unobserved difference between individual firms as a set of fixed parameters, and assumes differences in intercepts across groups or time periods.

\section{RESULTS}

In this study, we attempted to understand the role of attainment discrepancy, organizational slack and Altman's $Z$ in determining FDI intensity. Table 1 presents means, standard deviations, and correlations for all the variables in this study. Table 2 displays the results of fixed-effects panel regression regarding the effects of key variables on FDI intensity. Tables 3 and 4 show the fixed-effects panel regression by splitting the dataset using the unabsorbed slack and potential slack as a base, respectively. Table 5 presents the effects of distance to bankruptcy upon FDI intensity by separating the sample into low and high Altman's Z group.

Table 1 shows the descriptive statistics for the data set, consisting of 7,290 observations from 1996 to 2006. Aspiration (firm and industry based aspiration), attainment discrepancy( both underperformance and outperformance), unabsorbed slack, $\mathrm{R}$ and $\mathrm{D}$, and Altman's Z associate positively with FDI intensity, while potential slack and gross profit margin associate negatively with FDI intensity. The attainment discrepancy variables using firm and industry based aspiration correlate highly with each other (0.482), but the correlation between the firm based aspiration and industry based aspiration is modest $(0.274)$.

Table 2 shows the results of fixed-effects panel regression based on Equation 1. The pair columns in this table and other tables consist of firm and industry based aspiration, respectively. The first pair of columns (Model 1) presents the results after adding the industry's FDI and growth. The second pair of columns (Model 2) presents the coefficients after adding the set of variables attainment discrepancy to the baseline model. The third pair of columns (Model 3) presents the coefficients after adding the set of variables organizational slack to the baseline and attainment discrepancy model. The forth pair of columns (Model 4) shows the results after adding $R \& D$, Altman's Z, and gross profit margin. The $R^{2}$ of these models are above forty percent, providing a good indication of the explaining strength of the models. Meanwhile, the F-test is highly significant among the models.

In Table 2, the coefficients upon negative attainment discrepancy variable $(I=1$, firms' performances are below the aspiration levels) for both the firm-based and industry-based aspiration models are significantly positive. This finding implies that the farther the past performance falls below aspirations, the lower the firm's spending on FDI, not supporting Hypothesis 1a. For the outperformers $(I=0$, their performances are above the aspiration levels), the coefficients upon positive attainment discrepancy are mixed. The results are negative but insignificant for firm-based aspiration model, while the results for the industry-based aspiration model are negative and significant. This finding implies that the farther the past performance is above industry-based aspiration, the more likely the firm is to spend money to launch a FDI. In addition, the evidence appears that industry aspiration is more relevant to firm's FDls. Just as the mixed arguments stated before Hypothesis $1 \mathrm{~b}$, the signs of the coefficients are also mixed, not supporting Hypothesis $1 \mathrm{~b}$. Overall, the findings are contradictory with the problemistic search argument.

As for control variables, industries' effects on firms' FDIs are significantly positive in the empirical results for all the models and individual groups, which may give a picture about the herd behaviors which dominate the FDls of Taiwanese firms. On the other hand, the positive association between $R$ and $D$ and FDI intensity shows that FDls may not be an alternative solution for $R$ and $D$.

Following Chen and Miller (2007), this study split organization slack, including unabsorbed slack and potential slack, into low and high sub-samples, and present the results in Tables 3 and 4, respectively.

Table 3 shows that the unabsorbed slack relates positively with FDI for both models of firm and industry based aspiration in all sub-samples, and significantly in 
Table 1. Descriptive statistics and Pearson correlation.

\begin{tabular}{|c|c|c|c|c|c|c|c|c|c|c|c|c|c|}
\hline Variable & Mean & S.D. & 1 & 2 & 3 & 4 & 5 & 6 & 7 & 8 & 9 & 10 & 11 \\
\hline 1.FDI $\mathrm{F}_{\mathrm{i}, \mathrm{t}}$ & 8.2 & 15.83 & - & & & & & & & & & & \\
\hline 2. FDI $_{\text {ind }, t}$ & 1.4 & 1.03 & 0.16 & - & & & & & & & & & \\
\hline 3.GROWTH ${ }_{\text {ind, }}$ & 116.6 & 323.21 & -0.05 & -0.18 & - & & & & & & & & \\
\hline 4.(Performance- Aspiration $)_{\mathrm{i}, \mathrm{t}-1}$ & -0.7 & 8.51 & 0.03 & -0.03 & 0.04 & - & & & & & & & \\
\hline 5.(Performance- Aspiration $)_{\text {ind,t-1 }}$ & 0.1 & 10.22 & 0.09 & -0.03 & 0.06 & 0.48 & - & & & & & & \\
\hline 6.Aspiration $\mathrm{i}_{\mathrm{i}, \mathrm{t}-1}$ & 6.6 & 10.00 & 0.09 & 0.04 & 0.05 & -0.39 & 0.60 & - & & & & & \\
\hline 7.Aspiration ind,t-1 $_{1}$ & 5.8 & 2.25 & 0.09 & 0.22 & 0.11 & -0.13 & -0.06 & 0.27 & - & & & & \\
\hline 8.Unabsorbed Slack $\mathrm{i}_{\mathrm{i}, \mathrm{t}-1}$ & 155.6 & 204.03 & 0.01 & 0.09 & 0.00 & 0.01 & 0.211 & 0.18 & 0.08 & - & & & \\
\hline 9.Potential Slack $\mathrm{i}_{\mathrm{i}, \mathrm{t}-1}$ & 39.7 & 16.00 & -0.04 & -0.01 & -0.02 & -0.04 & -0.32 & -0.30 & -0.03 & -0.43 & - & & \\
\hline 10. $R$ and $D_{i, t}$ & 21.7 & 31.94 & 0.04 & 0.16 & 0.01 & -0.06 & 0.056 & 0.15 & 0.22 & 0.23 & -0.20 & - & \\
\hline 11.Altman's $Z_{i, t}$ & 1.3 & 1.08 & 0.08 & 0.06 & 0.04 & 0.18 & 0.55 & 0.45 & 0.18 & 0.13 & -0.14 & 0.12 & - \\
\hline 12.Gross Profit margin $n_{i, t}$ & 15.3 & 232.80 & -0.02 & 0.01 & 0.00 & 0.01 & 0.04 & 0.01 & 0.00 & 0.03 & -0.00 & 0.04 & 0.07 \\
\hline
\end{tabular}

Correlations with absolute values greater than 0.025 are significant at the $p<0.05$ level.

the lower unabsorbed slack sub-samples. This result is consistent with the anticipation of Hypothesis 2. The significance upon unabsorbed slack variable in the lower unabsorbed slack sub-sample means that unabsorbed slack is more relevant for the FDI decisions of firms with slim unabsorbed slack, and also implies that firms with limited unabsorbed slack will be more conservative in the allocation of resources.

Table 4 shows that the potential slack, as this study anticipates, relates negatively with FDI for both firm and industry based aspiration. The underlying rationale is that lower potential slack variable (debt-to-equity ratio) typically indicates more potential borrowing capacity, and therefore greater financial flexibility. This may creates an incentive for firms to take advantage of debt financing in increasing their FDIs.

The significance of potential slack variable only appears in the higher $50 \%$ potential slack (lower $50 \%$ potential borrowing capacity) sub-samples, which implies that firms with low financial flexibility pay more attention to borrowing capacity when launching FDIs than their peer firms do.

These findings imply that the organizational slack plays an important role in FDI intensity and decisions, in support of Hypothesis 2.

Does distance from bankruptcy affect a firm's FDI intensity? The study split the sub-samples of underperformers and out-performers into lower and higher groups by distance from bankruptcy, respectively. Table 5 shows the results for fixed effects panel regression, basing the estimation for the models on Equation 2. The columns present the results for both the underperforming and outperforming firms relative to the firm and industry based aspiration, using the means of the Altman's Z as a split point.

In Table 5, the study divided the sample into higher and lower Altman's Z groups. Though insignificant, the coefficient upon Altman's $Z$ for underperforming and outperforming firms in both firm and industry based aspiration model is positive in the lower $Z$ group, but negative in the higher $Z$ group. The opposite signs in the both groups are consistent with the anticipation of Hypothesis $3 a$ and $3 b$, respectively. The results indicate that firms not directly threatened by bankruptcy, their foci may shift to aspiration levels. That is, FDI intensity increases as the distance to bankruptcy decreases, but the premise is that the firm is not directly threatened by bankruptcy. As for firms directly threatened by bankruptcy, the FDI intensity tends to decrease as they approach bankruptcy. The key point is that their foci shift from aspiration to survival levels, which makes the coefficients change the directions. Further inference is that firms may change their attitudes toward risk taking as the situations change.

On the other hand, the unabsorbed slack coefficients in the high $\mathrm{Z}$ group for both the underperformers and outperformers are significantly positive, while the potential slack coefficients in the low $Z$ group are significantly negative. This finding indicates that both the high and low $Z$ group launching into FDI will rationally evaluate their financial abilities. The high $Z$ group, less threatened by bankruptcy, put more emphasis upon unabsorbed slack, whereas the low Z group, more threatened by bankruptcy, put more emphasis upon potential slack.

Finally, apart from employing the Hausman test to determine the use of the fixed-effects model, we also performed several robustness tests to increase the reliability of the empirical results.

The tests included using a sample of firms with only positive FDI, adopting the mean, $25^{\text {th }}$, and $75^{\text {th }}$ percentile as a split point, and retesting with TOBIT models. The tests obtained similar results and corresponded with our main findings. 
Table 2. Results of fixed-effect panel regressions for FDI intensity.

\begin{tabular}{|c|c|c|c|c|c|c|c|c|}
\hline \multirow[b]{2}{*}{ Variables } & \multicolumn{2}{|c|}{ Model 1} & \multicolumn{2}{|c|}{ Model 2} & \multicolumn{2}{|c|}{ Model 3} & \multicolumn{2}{|c|}{ Model 4} \\
\hline & $\begin{array}{c}\text { Firm } \\
\text { aspiration }\end{array}$ & $\begin{array}{c}\text { Industry } \\
\text { aspiration }\end{array}$ & $\begin{array}{c}\text { Firm } \\
\text { aspiration }\end{array}$ & $\begin{array}{c}\text { Industry } \\
\text { aspiration }\end{array}$ & $\begin{array}{c}\text { Firm } \\
\text { aspiration }\end{array}$ & $\begin{array}{c}\text { Industry } \\
\text { aspiration }\end{array}$ & $\begin{array}{c}\text { Firm } \\
\text { aspiration }\end{array}$ & $\begin{array}{c}\text { Industry } \\
\text { aspiration }\end{array}$ \\
\hline $\mathrm{FDl}_{\text {ind,t }}$ & $2.464^{\star \star \star}(0.243)$ & $3.723^{\star \star \star}(0.360)$ & $2.580^{\star \star \star}(0.223)$ & $3.974^{\star \star \star}(0.330)$ & $2.579^{\star \star \star}(0.223)$ & $3.907^{\star * \star}(0.330)$ & $2.5668^{\star \star \star}(0.256)$ & $2.5879^{\star \star \star}(0.255)$ \\
\hline Growth $_{\text {ind,t }} \mathrm{b}$ & $-0.001^{\star \star}(0.001)$ & $-0.001(0.001)$ & $-0.131^{\star *}(0.053)$ & $-0.002^{\star \star} 0.001$ & $-0.138^{\star \star *}(0.053)$ & $-0.161^{* \star}(0.075)$ & $-0.1092^{\star \star}(0.055)$ & $-0.1205^{\star \star}(0.055)$ \\
\hline $\mathrm{l}_{\mathrm{i}}\left(\right.$ Performance $_{\mathrm{i}, \mathrm{t}-1}-$ Aspiration $\left._{\mathrm{i}, \mathrm{t}-1}\right)$ & & & $0.107^{\star \star \star}(0.033)$ & $0.182^{\star \star *} 0.042$ & $0.097^{\star \star \star}(0.033)$ & $0.135^{\star \star \star}(0.044)$ & $0.0868^{\star \star \star}(0.033)$ & $0.1239^{\star \star \star}(0.033)$ \\
\hline$\left(1-\mathrm{I}_{\mathrm{i}}\right)\left(\right.$ Performance $_{\mathrm{i}, t-1}-$ Aspiration $\left._{\text {ind }, t-1}\right)$ & & & $-0.014(0.037)$ & $0.216^{* * *}(0.062)$ & $-0.010(0.038)$ & $0.188^{* * *}(0.062)$ & $-0.0106(0.038)$ & $0.0977^{* *}(0.045)$ \\
\hline Unabsorbed Slack $\mathrm{k}, t-1^{\mathrm{b}}$ & & & & & $0.410^{* \star}(0.168)$ & $0.797^{\star * \star}(0.234)$ & $0.3884^{* *}(0.168)$ & $0.3122^{*}(0.167)$ \\
\hline Potential Slack $k_{i, t-1}$ & & & & & $-0.055^{\star \star *}(0.019)$ & $-0.069 * *(0.028)$ & $-0.0584^{\star \star \star}(0.020)$ & $-0.0439^{\star *}(0.020)$ \\
\hline$R$ and $D_{i, t}$ & & & & & & & $0.0360^{* *}(0.016)$ & $0.0373^{* \star}(0.016)$ \\
\hline Altman's $Z_{i, t}$ & & & & & & & $0.4511(0.294)$ & $0.1981(0.285)$ \\
\hline Gross Profit Margin $_{i, t}$ & & & & & & & $0.0017(0.025)$ & $-0.0003(0.001)$ \\
\hline $\mathrm{N}$ & 7343 & 7445 & 7331 & 7443 & 7331 & 7443 & 7278 & 7288 \\
\hline $\mathrm{F}$ & $3.73^{* \star *}$ & $3.49^{\star \star \star}$ & $3.74^{\star * *}$ & $3.55^{\star * *}$ & $3.76^{\star \star \star}$ & $3.58^{* * *}$ & $3.77^{\star \star \star}$ & $3.79^{\star \star \star}$ \\
\hline $\mathrm{R}^{2}$ & 0.4237 & 0.4055 & 0.4249 & 0.4094 & 0.4270 & 0.4119 & 0.4305 & 0.4320 \\
\hline
\end{tabular}

a Two-sided significance test. Standard error are in parentheses; ${ }^{*} \mathrm{p}<0.10 ;{ }^{* *} \mathrm{p}<0.05 ;{ }^{* * *} \mathrm{p}<0.01 ; \mathrm{b}$ The coefficients and standard errors are multiplied by 102 .

Table 3. Fixed-effects panel regressions for FDI intensity: Result for four sub-samples, split by unabsorbed slacks ${ }^{\mathrm{a}}$.

\begin{tabular}{|c|c|c|c|c|c|c|c|c|}
\hline \multirow{3}{*}{ Variables } & \multicolumn{4}{|c|}{ Underperformers } & \multicolumn{4}{|c|}{ Outperformers } \\
\hline & \multicolumn{2}{|c|}{ Lower $50 \%$ unabsorbed slack } & \multicolumn{2}{|c|}{ Higher $50 \%$ unabsorbed slack } & \multicolumn{2}{|c|}{ Lower $50 \%$ unabsorbed slack } & \multicolumn{2}{|c|}{ Higher $50 \%$ unabsorbed slack } \\
\hline & $\begin{array}{c}\text { Firm } \\
\text { aspiration }\end{array}$ & $\begin{array}{l}\text { Industry } \\
\text { aspiration }\end{array}$ & $\begin{array}{c}\text { Firm } \\
\text { aspiration }\end{array}$ & $\begin{array}{l}\text { Industry } \\
\text { aspiration }\end{array}$ & $\begin{array}{c}\text { Firm } \\
\text { aspiration }\end{array}$ & $\begin{array}{l}\text { Industry } \\
\text { aspiration }\end{array}$ & $\begin{array}{c}\text { Firm } \\
\text { aspiration }\end{array}$ & $\begin{array}{l}\text { Industry } \\
\text { aspiration }\end{array}$ \\
\hline$\overline{\mathrm{FDl}_{\text {ind }, \mathrm{t}}}$ & $2.272^{\star \star \star}(0.361)$ & $2.293^{\star \star \star}(0.361)$ & $3.033^{\star \star \star}(0.487)$ & $3.128^{\star \star \star}(0.487)$ & $3.033^{\star \star \star}(0.424)$ & $3.118^{\star \star \star}(0.432)$ & $2.960^{\star * \star}(0.527)$ & $3.109^{\star \star \star}(0.526)$ \\
\hline Growth $_{\text {ind,t }} \mathrm{b}$ & $0.001(0.062)$ & $-0.001(0.062)$ & $-0.174(0.158)$ & $-0.250(0.158)$ & $-0.086(0.100)$ & $-0.101(0.100)$ & $-0.399^{\star *}(0.163)$ & $-0.469^{\star \star *}(0.164)$ \\
\hline Performance $_{t-1}-$ Aspiration $_{t-1}$ & $0.013(0.028)$ & $0.049(0.038)$ & $0.120^{\star * *}(0.046)$ & $0.138^{\star \star *}(0.053)$ & $-0.023(0.054)$ & $0.072(0.075)$ & $0.033(0.051)$ & $0.168^{\star * \star}(0.065)$ \\
\hline Unabsorbed slack $\mathrm{i}_{\mathrm{t}-\mathrm{-}-1}^{\mathrm{b}}$ & $8.990^{\star * *}(1.682)$ & $8.841^{\star \star \star}(1.684)$ & $0.261(0.246)$ & $0.192(0.247)$ & $4.898^{\star \star *}(1.808)$ & $4.751^{\star \star \star}(1.812)$ & $0.352(0.281)$ & $0.252(0.281)$ \\
\hline Potential slack $\mathrm{i}_{\mathrm{i}, \mathrm{t}-1}$ & $-0.016(0.032)$ & $-0.006(0.033)$ & $0.035(0.046)$ & $0.051(0.047)$ & $-0.090^{\star *}(0.043)$ & $-0.083^{*}(0.043)$ & $0.122^{\star *}(0.050)$ & $0.130^{\star * \star}(0.050)$ \\
\hline$R$ and $D_{i, t}$ & $-0.014(0.034)$ & $-0.014(0.034)$ & $0.023(0.026)$ & $0.020(0.026)$ & $-0.037(0.055)$ & $-0.035(0.055)$ & $0.086^{\star \star \star}(0.030)$ & $0.090^{* \star *}(0.030)$ \\
\hline Altman's $Z_{\mathrm{l}, \mathrm{t}}$ & $0.941^{\star \star}(0.394)$ & $0.892^{* *}(0.395)$ & $-0.801(0.674)$ & $-1.092(0.695)$ & $0.470(0.618)$ & $0.319(0.632)$ & $-1.242(0.870)$ & $-1.749^{*}(0.885)$ \\
\hline Gross profit margin $_{\mathrm{i}, \mathrm{t}}$ & $0.010(0.034)$ & $0.007(0.034)$ & $-0.002(0.056)$ & $0.000(0.056)$ & $-0.024(0.049)$ & $-0.027(0.049)$ & $-0.003(0.069)$ & $-0.018(0.069)$ \\
\hline N & 2542 & 2544 & 2553 & 2555 & 2438 & 2443 & 2437 & 2442 \\
\hline$F$ & $2.54^{* \star *}$ & $2.54^{\star \star \star}$ & $2.16^{\star \star \star}$ & $2.15^{\star \star \star}$ & $2.75^{\star \star *}$ & $2.75^{\star \star \star}$ & $2.53^{\star \star \star}$ & $2.54^{\star \star *}$ \\
\hline$R^{2}$ & 0.5027 & 0.5035 & 0.5341 & 0.5341 & 0.5816 & 0.5818 & 0.5738 & 0.5758 \\
\hline
\end{tabular}

a) Cut-off points are the means of unabsorbed slack; b) The coefficients and standard errors are multiplied by $102 ; \mathrm{c})$ Two-sided significance test. Standard error are in parentheses; $\mathrm{p}<0.10 ;{ }^{* *} \mathrm{p}<$ $0.05 ;{ }^{* \star \star} p<0.01$. 
Table 4. Fixed-effects panel regressions for FDI intensity: Result for four sub-samples, split by potential slacks ${ }^{a}$.

\begin{tabular}{|c|c|c|c|c|c|c|c|c|}
\hline \multirow{3}{*}{ Variables } & \multicolumn{4}{|c|}{ Underperformers } & \multicolumn{4}{|c|}{ Outperformers } \\
\hline & \multicolumn{2}{|c|}{ Lower $50 \%$ potential slack } & \multicolumn{2}{|c|}{ Higher $50 \%$ potential slack } & \multicolumn{2}{|c|}{ Lower $50 \%$ potential slack } & \multicolumn{2}{|c|}{ Higher $50 \%$ potential slack } \\
\hline & $\begin{array}{c}\text { Firm } \\
\text { aspiration }\end{array}$ & $\begin{array}{c}\text { Industry } \\
\text { aspiration }\end{array}$ & $\begin{array}{c}\text { Firm } \\
\text { aspiration }\end{array}$ & $\begin{array}{c}\text { Industry } \\
\text { aspiration }\end{array}$ & $\begin{array}{c}\text { Firm } \\
\text { aspiration }\end{array}$ & $\begin{array}{c}\text { Industry } \\
\text { aspiration }\end{array}$ & $\begin{array}{c}\text { Firm } \\
\text { aspiration }\end{array}$ & $\begin{array}{c}\text { Industry } \\
\text { aspiration }\end{array}$ \\
\hline $\mathrm{FDl}_{\text {ind }, \mathrm{t}}$ & $2.806^{* * *}(0.455)$ & $2.930^{\star * \star}(0.459)$ & $2.142^{* * *}(0.383)$ & $2.186^{* * *}(0.382)$ & $2.973^{* * *}(0.489)$ & $3.102^{* * *}(0.490)$ & $2.775^{\star * \star}(0.450)$ & $2.757^{* * *}(0.455)$ \\
\hline Growth $_{\text {ind }, t} \mathrm{~b}^{2}$ & $-0.161(0.107)$ & $-0.183^{*}(0.107)$ & $0.024(0.075)$ & $0.016(0.074)$ & $-0.221(0.155)$ & $-0.251(0.156)$ & $-0.147(0.102)$ & $-0.168(0.103)$ \\
\hline Performance $_{\mathrm{t}-1}-$ Aspiration $_{\mathrm{t}-1}$ & $0.081 *(0.049)$ & $0.094^{*}(0.055)$ & $0.041(0.028)$ & $0.078^{\star \star}(0.038)$ & $0.049(0.050)$ & $0.111^{*}(0.062)$ & $-0.039(0.051)$ & $0.071(0.073)$ \\
\hline Unabsorbed Slack $k_{i, t-1}{ }^{b}$ & $0.458^{\star}(0.273)$ & $0.373(0.276)$ & $2.358^{\star \star \star}(0.769)$ & $2.177^{\star \star \star}(0.773)$ & $0.371(0.274)$ & $0.306(0.276)$ & $3.217^{\star \star \star}(0.796)$ & $2.683^{\star \star \star}(0.760)$ \\
\hline Potential Slack $k_{i, t-1}$ & $0.017(0.058)$ & $0.026(0.058)$ & $-0.076^{* *}(0.035)$ & $-0.061^{*}(0.036)$ & $0.056(0.066)$ & $0.058(0.066)$ & $-0.128^{* \star}(0.047)$ & $-0.126^{* * *}(0.048)$ \\
\hline$R$ and $D_{i, t}$ & $0.019(0.027)$ & $0.016(0.027)$ & $0.037(0.030)$ & $0.037(0.030)$ & $0.069^{* *}(0.030)$ & $0.069^{* *}(0.030)$ & $0.064(0.040)$ & $0.067^{\star}(0.040)$ \\
\hline Altman's $Z_{i, t}$ & $0.034(0.634)$ & $-0.097(0.646)$ & $0.608(0.409)$ & $0.506(0.415)$ & $-0.245(0.897)$ & $-0.507(0.912)$ & $0.035(0.600)$ & $-0.147(0.617)$ \\
\hline Gross Profit margin $_{i, t}$ & $0.030(0.051)$ & $0.029(0.051)$ & $-0.002(0.035)$ & $-0.001(0.035)$ & $-0.081(0.061)$ & $-0.087(0.061)$ & $-0.002(0.055)$ & $-0.007(0.055)$ \\
\hline $\mathrm{N}$ & 2553 & 2554 & 2542 & 2545 & 2440 & 2443 & 2435 & 2442 \\
\hline $\mathrm{F}$ & $2.28^{\star * \star}$ & $2.28^{\star * \star}$ & $2.76^{\star \star \star}$ & $2.76^{\star \star *}$ & $2.75^{\star \star \star}$ & $2.76^{\star \star *}$ & $2.82^{\star \star \star}$ & $2.82^{* \star *}$ \\
\hline $\mathrm{R}^{2}$ & 0.5159 & 0.5160 & 0.5378 & 0.5378 & 0.5716 & 0.5722 & 0.5929 & 0.5923 \\
\hline
\end{tabular}

a) Cut-off points are the means of potential slack; b) The coefficients and standard errors are multiplied by $10 ; c)$ Two-sided significance test. Standard error are in parentheses; $\mathrm{k}<0.10$; ${ }^{* *} \mathrm{p}<0.05$;

a) Cut-off point

Table 5. Fixed-effects panel regressions for FDI intensity: Result for four sub-samples, split by Altman's Za

\begin{tabular}{|c|c|c|c|c|c|c|c|c|}
\hline \multirow{3}{*}{ Variables } & \multicolumn{4}{|c|}{ Underperformers } & \multicolumn{4}{|c|}{ Outperformers } \\
\hline & \multicolumn{2}{|c|}{ Lower $50 \%$ Z } & \multicolumn{2}{|c|}{ Higher $50 \%$ Z } & \multicolumn{2}{|c|}{ Lower $50 \%$ Z } & \multicolumn{2}{|c|}{ Higher $50 \%$ Z } \\
\hline & $\begin{array}{c}\begin{array}{c}\text { Firm } \\
\text { aspiration }\end{array} \\
\end{array}$ & $\begin{array}{c}\text { Industry } \\
\text { aspiration }\end{array}$ & $\begin{array}{c}\begin{array}{c}\text { Firm } \\
\text { aspiration }\end{array} \\
\end{array}$ & $\begin{array}{c}\text { Industry } \\
\text { aspiration }\end{array}$ & $\begin{array}{c}\begin{array}{c}\text { Firm } \\
\text { aspiration }\end{array} \\
\end{array}$ & $\begin{array}{c}\text { Industry } \\
\text { aspiration }\end{array}$ & $\begin{array}{c}\text { Firm } \\
\text { aspiration }\end{array}$ & $\begin{array}{c}\text { Industry } \\
\text { aspiration }\end{array}$ \\
\hline FDl ${ }_{\text {ind,t }}$ & $2.124^{\star \star \star}(0.361)$ & $2.115^{\star \star \star}(0.359)$ & $2.642^{\star \star \star}(0.500)$ & $2.876^{\star \star \star}(0.502)$ & $2.757^{\star \star \star}(0.408)$ & $2.799^{\star \star \star}(0.411)$ & $3.248^{\star \star \star}(0.547)$ & $3.440^{\star \star *}(0.547)$ \\
\hline Growth $_{\text {ind, } t} \mathrm{~b}$ & $-0.032(0.072)$ & $-0.035(0.071)$ & $-0.139(0.109)$ & $-0.176(0.109)$ & $-0.024(0.111)$ & $-0.047(0.112)$ & $-0.362^{\star \star}(0.145)$ & $-0.418^{* * *}(0.145)$ \\
\hline Performance $_{t-1}-$ Aspiration $_{t-1}$ & $0.007(0.026)$ & $0.051(0.035)$ & $0.197^{\star \star \star}(0.060)$ & $0.196^{\star \star *}(0.061)$ & $-0.042(0.048)$ & $0.083(0.062)$ & $0.051(0.054)$ & $0.235^{\star \star *}(0.070)$ \\
\hline Unabsorbed slack $\mathrm{k}_{\mathrm{i}, \mathrm{t}-1} \mathrm{~b}$ & $0.129(0.211)$ & $0.111(0.208)$ & $1.194^{* \star *}(0.440)$ & $1.008^{\star *}(0.440)$ & $0.155(0.239)$ & $0.083(0.239)$ & $1.151^{\star \star}(0.473)$ & $1.102^{* *}(0.468)$ \\
\hline Potential slack $\mathrm{i}_{\mathrm{t}-\mathrm{1}}$ & $-0.054^{\star \star}(0.027)$ & $-0.043^{\star}(0.025)$ & $-0.029(0.045)$ & $-0.001(0.045)$ & $-0.084^{\star \star}(0.035)$ & $-0.078^{\star \star}(0.035)$ & $-0.008(0.049)$ & $0.015(0.049)$ \\
\hline$R$ and $D_{i, t}$ & $0.031(0.025)$ & $0.031(0.025)$ & $0.053(0.034)$ & $0.056 *(0.034)$ & $0.059(0.037)$ & $0.064^{*}(0.037)$ & $0.089^{\star \star \star}(0.032)$ & $0.097^{\star \star}(0.032)$ \\
\hline Altman's $Z_{i, t}$ & $0.669(0.409)$ & $0.635(0.387)$ & $-0.368(0.945)$ & $-0.803(0.964)$ & $0.707(0.747)$ & $0.502(0.754)$ & $-0.016(0.917)$ & $-0.632(0.927)$ \\
\hline Gross profit margi $i, t$ & $0.009(0.029)$ & $-0.001(0.001)$ & $-0.072(0.087)$ & $-0.099(0.088)$ & $0.011(0.043)$ & $0.007(0.043)$ & $-0.223^{* *}(0.093)$ & $-0.243^{* * *}(0.093)$ \\
\hline $\mathrm{N}$ & 2540 & 2541 & 2555 & 2557 & 2439 & 2443 & 2435 & 2441 \\
\hline $\mathrm{F}$ & $2.92^{\star \star \star}$ & $2.93^{\star \star \star}$ & $2.09^{\star \star \star}$ & $2.09^{\star \star \star}$ & $3.07^{\star \star \star}$ & $3.07^{\star \star \star}$ & $2.54^{\star \star \star}$ & $2.57^{\star \star \star}$ \\
\hline$R^{2}$ & 0.4817 & 0.4826 & 0.5374 & 0.5375 & 0.5792 & 0.5793 & 0.5636 & 0.5669 \\
\hline
\end{tabular}

a) Cut-off points are the means of Altman's Z. b) The coefficients and standard errors are multiplied by 10 . c) Two-sided significance test. Standard error are in parentheses; ${ }^{*} \mathrm{p}<0.10$; ${ }^{* *} \mathrm{p}<0.05 ;{ }^{* * *} \mathrm{p}<$ 0.01 . 


\section{DISCUSSION AND CONCLUSION}

This study builds from the behavioral theory of the firm (Cyert and March, 1963) and the resource-based view of the firm (Wernerfelt, 1984) to provide in-depth profiles of firms' decision making and the role of attainment discrepancy in the behaviors of firms who engage in FDIs. Given the political tension and potential conflicts between Taiwan and the China during the study period, the Taiwanese firms' FDIs into China is thus an ideal target for research on search intensity and risky behaviors.

Researchers who studied firms behaviors, such as, Chen and Miller (2004, 2007), Gooding et al. (1996), and Greve (2003a), widely cite March and Shapira's (1987) model for allowing for shifts in attention between survival and aspiration levels. Miller and Chen (2004) primarily use variables of distance from bankruptcy, performance and aspiration levels to examine variable organizational risk preferences, and perform tests on the March and Shapira Model. Following Greve's (2003a) approach, this study examines the association between firms' FDls and the performances relative to their aspiration levels. Greve (2003a) uses the spline function (Greene, 2008) to yield separate tests of his hypothesis for performance above and below aspiration level with a view to making the models comparable. Instead of using $R$ and $D$ expenditures of firms as a proxy variable for search intensity (Chen and Miller, 2007), the present study uses the FDI intensity of Taiwan listed companies as the dependent variable of the firms' search intensity and relevant risky behaviors. Apart from performance, aspiration levels and distance from bankruptcy (Miller and Chen, 2004, 2007), we added several industry-level and firm-level variables to make the results more reliable.

The findings are largely consistent with the expectations based upon Cyert and March's (1963) behavioral theory and prior research which suggest that rigidity or conservatism occurs when firms face risk (Staw et al., 1981; March and Shapira, 1992). As for the question of problemistic or slack search, the empirical results show that slack search is more applicable for explaining what conditions in which firms tend to implement FDIs. Namely, the resource-based view plays an important role for the decision process of FDI.

The evidence of this study shows that the farther the firms' performances are below their aspirations, the less willing the firms is to launch their overseas investment plans. This result is not consistent with the problemistic search argument of the behavioral theory. To delve into the background, an underperforming firm with performance distantly below aspiration may focus more on survival, and more likely to keep their existing operations as usual and avoid searching for FDIs. In contrast, adding slack variables to the model results in significant coefficients, which suggest that slack search plays an important role for firms in lauching FDIs. In addition, the fact that the reference point of industry based aspiration turns the coefficients upon the positive attainment discrepancy variable from insignificant to significant shows that industry benchmark is highly relevant when firms are making their FDI decisions. This evidence appears that Taiwanese firms strive to outperform their peer firms by launching FDIs, especially when firms have enough organizational slack.

Both unabsorbed slack and potential slack associates significantly with FDI intensity in the full sample. In the lower unabsorbed group and higher potential slack (higher debt-to-equity or lower potential borrowing capacity) group, the coefficients are also significant. Both findings are consistent with the expectation on slack variables (Hypothesis 2), and indicate that firms' organizational slack and potential borrowing capacity associate with FDI. The evidence in the sub-samples also implies that firms with slim financial resources (including available unabsorbed slack and potential borrowing capacity) are more conservative and discreet in the allocation of resources when launching FDI projects. On the other hand, the significance of attainment discrepancy coefficients in the higher organizational slack group, that is, higher $50 \%$ unabsorbed slack and lower $50 \%$ potential slack variable (higher $50 \%$ potential borrowing capacity), means that focus of attention on aspirations is relevant only when firms have higher organizational slack. This result informs us that organizational slack has higher priority than performance relative to aspirations. Since the financial resources of firms are highly relevant to organizational developments, firms with a plan of increasing or launching FDIs inevitably have to consider their available resources (unabsorbed slack) and potential resources (potential borrowing capacity) first.

With respect to the perceived threat of firms to become bankrupt, the present study shows that firms' FDI intensity with high proximity to bankruptcy is obviously different from that of the firms with low proximity. Our empirical result presents that when the Altman's Z gets lower, firms directly threatened by bankruptcy tend to decrease their risk taking; whereas firms not directly threatened by bankruptcy tend to increase their risk taking, though the evidence is weak. This reversal in the signs of the coefficients upon the Altman's $Z$, is similar to the argument that managers shift their foci of attention from survival to aspiration levels as firms improve their performances. Meanwhile, when making FDI decisions, firms in high $Z$ group (less threatened by bankruptcy) tend to focus on unabsorbed slack, while firms in low $Z$ group (more threatened by bankruptcy) tend to put more emphasis on potential slack. These finding informs us that managers may shift their from pursuing aspiration to avoiding bankruptcy and focus on either unabsorbed slack or potential slack when making FDI decisions, depending on their situations.

Overall, the empirical results of this study provides evidence which is largely consistent with the contention that managers of underperforming firms recognize their duties 
to avoid placing their firms at risk (March and Shapira, 1987). Meanwhile, the results are not consistent with Greve's (2003b) problemistic search arguments that when the performance relative to aspiration level decreases, search intensity increases. In contrast, our findings show that more organizational slacks bring more FDls for both underperforming and outperforming firms, especially for the firms with slim organizational slacks. In other words, the potential triggers for increasing or launching FDIs would rather be organizational slack than underperformance. Therefore, slack search is more appropriate than problemistic search in explaining firms FDI behaviors. On the other hand, the sign reversals of the Altman's Z coefficients inform us concerning the existence of a turning point where managers change their foci of attention. This finding confirms the March and Shapira's $(1987,1992)$ argument that managers of firms focusing on survival tend to be more risk averse and managers of firms focusing on aspiration levels are more willing to take risk. Finally, the different focal points of both high Z group and low Z group imply that organizational slack also plays an essential role for managers' attention shift.

The behavioral theory of the firm, as Greve (2003b) suggests, provides a good platform for integrating development and decision making ideas toward innovation. The study's findings indicate that the resource-based view offers an appropriate foundation for interpreting firms' FDIs. Besides the aspiration level and the peer firms' behaviors, organizational slack plays an essential role for the decision making of FDI projects and managers' attention shift. The present study is unique in using the classification of underperforming or outperforming relative to aspiration level to study FDI behaviors. Understanding how the role of organizational slack and attainment discrepancy plays in FDI behaviors and the shifts of managers' attention can help outsiders such as investors and policymakers identify firms strategy and modify investment strategies or policies. From our empirical results, this study infers that internally firms' FDI behaviors gain momentum first from organizational slack and then the higher performance relative to aspiration levels. Externally, firms' FDIs are highly affected by the behaviors of the firms in the same industry. Finally, since the vast and fast-growing market of China is so attractive to many multinational firms, this study may offer an insight into how the firms in this market behave. However, future studies may further explore the global market or extend the present study to examine the interaction between FDI and $R$ and $D$, which represent two different types of solutions for firms to respond to changing environments and challenges.

\section{ACKNOWLEDGEMENT}

We are indebted to two anonymous referees for sowing the seeds for this research in many valued feedbacks and insightful comments. We also appreciate the Editor and related units for a lot of help. Finally, we wish to acknowledge the funding support from the National Science Council, ROC (NSC99-2410-H-265-006-).

\section{REFERENCES}

Altman El (1983).Corporate Distress: A Complete Guide to Predicting, Avoiding, and Dealing with Bankruptcy. Wiley: New York.

Audia PG, Locke EA, Smith KG (2000). The paradox of success: An archival and a laboratory study of strategic persistence following a radical environmental change. Acad. Manag. J. 43:837-853.

Barney JB (1986). Strategic factor markets: Expectation, luck, and business strategy. Manag. Sci. 32(10):1231-1241.

Baum JA, Rowley TC, Shipilov AV, Chuang YT (2005). Dancing with strangers: aspiration performance and the search for underwriting syndicate partners. Adm. Sci. Q. 50:536-575.

Bowman EH (1982). Risk seeking by troubled firms. Sloan Manag. Rev. 23(4):33-42.

Bromiley $P$ (1991). Testing a causal model of corporate risk taking and performance. Acad. Manag. J. 34:37-59.

Chadee DD, Qiu F, Rose EL (2003). FDI location at the subnational level: a study of EJVs in China. J. Bus. Res. 56:835-845.

Chen CJ, Huang YF (2010). Creative workforce density, organizational slack, and innovation performance. J. Bus. Res. 63(4):411-417.

Chen WR, Miller KD (2007). Situational and institutional determinants of firms' R\&D search intensity. Strateg. Manag. J., 28: 369-381.

Cyert RM, March JG (1963). A Behavioral Theory of the Firm. Englewood Cliffs, Prentice-Hall, NJ.

D'Aveni RA, llinitch AY (1992). Complex patterns of vertical integration in the forest products industry: Systematic and bankruptcy risks. Acad. Manag. J. 35: 596-625.

Deephouse DL, Wiseman RM (2000). Comparing alternative explanations for accounting risk-return relations. J. Econ. Behav. Organ. 42:463-482.

Fiegenbaum A, Thomas H (1986). Dynamic and risk measurement perspectives on Bowman's risk-return paradox for strategic management: An empirical study. Strateg. Manag. J. 7:395-407.

Fiegenbaum A, Thomas $H$ (1988). Attitudes toward risk and the riskreturn paradox: Prospect theory explanations. Acad. Manag. J. 31:85106.

Galbreath J, Galvin P (2008). Firm factors, industry and performance variation: New empirical evidence to a classic debate. J. Bus. Res. 61:109-117.

Gooding, RZ, Goel S, Wiseman RM (1996). Fixed versus variable reference points in the risk-return relationship. J. Econ. Behav. Organ. 29:331-350.

Greene WH (2008). Econometric Analysis (6th ed.). New York: Pearson.

Greve HR (2003a). A behavioral theory of R\&D expenditures and innovations: Evidence from shipbuilding. Acad. Manag. J. 46(6):685702.

Greve HR (2003b). Organizational learning from performance feedback: A behavioral perspective on innovation and change. England: Cambridge University Press.

Greve HR (1998). Performance, aspirations, and risky organizational change. Admin. Sci. Q. 43(1):58-86.

Grinyer P, McKiernan P (1990). Generating major change in stagnating companies. Strateg. Manag. J. 11:131-146.

Jelinek M, Schoonhoven CB (1990). The Innovation Marathon: Lessons from High Technology Firms. England Oxford: Blackwell.

Jensen MC, Meckling WH (1976). Theory of the firm: Managerial behavior, agency Costs, and ownership structure. J. Financ. Econ. 3:305-360.

Kahneman D, Tversky A (1979). Prospect theory: An analysis of decision under risk. Econometrics 47:263-291.

Kogut B (1983). Foreign Direct Investment as a Sequential Process, in C. $P$.

Lant TK (1992). Aspiration level adaptation: An empirical exploration. Manag. Sci. 38:623-644.

Lant TK, Milliken FJ, Batra B (1992). The role of managerial learning 
and interpretation in strategic persistence and reorientation: An empirical exploration. Strateg. Manag. J. 13:585-608.

March JG (1994). A Primer on Decision Making: How Decisions Happen. New York: Free Press.

March JG (1981). Footnotes to organizational change. Admin. Sci. Q., 26:563-577.

March JG, Shapira Z (1987). Managerial perspectives on risk and risk taking. Manag. Sci. 33:1404-1418.

March JG, Shapira Z (1992). Variable risk preferences and the focus of attention. Psych. Rev. 99:172-183.

McNamara G, Bromiley P (1997). Decision making in an organizational setting: Cognitive and organizational influences on risk assessment in commercial lending. Acad. Manage. J. 40:1063-1088.

Miller KD, Chen WR (2004). Variable organizational risk preferences: Tests of the March-Shapira model. Acad. Manag. J. 47(1):105-116.

Miller KD, Leiblein MJ (1996). Corporate risk-return relations: Returns variability versus downside risk. Acad. Manag. J. 39:91-122.

Reuer JJ, Tong TW (2007). Corporate investments and growth options. Manag. Decis. Econ. 28(8):863-877.

Schneider SL (1992). Framing and conflict: Aspiration level contingency, the status quo, and current theories of risky choice. J. Exp. Psychol. Learn. 18:1040-1057.

Singh JV (1986). Performance, slack, and risk raking in organizational decision making. Acad. Manag. J. 29:562-585.

Staw BM, Sandelands LE, Dutton JE (1981). Threat-rigidity effects in organizational behavior: A multilevel analysis. Admin. Sci. Q. 26:501524.
Tversky A, Kahneman D (1992). Advances in prospect theory: Cumulative representation of uncertainty. J. Risk. Uncertainty 5:297323.

Tversky A, Kahneman D (1991). Loss aversion in riskless choice: A reference-dependent model. Q. J. Econ. 106:1039-1061.

Wernerfelt B (1984). A resourced-based view of the firm. Strateg. Manag. J. 5(3):171-180

Wiseman RM, Bromiley P (1996). Toward a model of risk in declining organizations: An empirical examination of risk, performance and decline. Organ., Sci. 7: 524-543.

Wooldridge JM (2006). Introductory Econometrics: A Modern Approach (3rd ed). OH: Thomson. 